\title{
Recording the ciliated parasite Vorticella globularia on the gill of a new host Cyprinion macrostomum Heckel, 1843 for the first time in Iraq
}

\author{
Bashar Abdul-Hussain Al-Sa'adi \\ Al-Musaib- Technical College \\ Emall; ellewialsaadi@yahoo.co.uk \\ Emall; com.bash2@atu.edu.iq
}

\begin{abstract}
:
Nine Cyprinion macrostomum fishes had been collecting from fishermen that fishing by throw net from Euphrates river Al-mussab city, it had been measured and weighted, its weight 8.5-46 gm, and its length 9.5$16 \mathrm{~cm}$ respectively and then examined it, throughout looking for parasite infection, ciliated was arise, then start measuring it and comparing it with what the taxonomy references and what other researcher find, it look the seam with what Al-Musawi, (2016) recoded and what Warren, (1986) mentioned, then by e-mailing Pro. Dr. F.D. Mhaisen, and after he checked his Index-catalogue, Mhaisen, F.T. (2019), the parasite considered as a new intrusive on $C$. macrostomum fish and this fish as a new host for it in Iraq.
\end{abstract}

Key words: Cyprinion macrostomum, Vorticella globularia and fish parasite.

\section{Introduction}

Cyprinion macrostomum its one of the Iraqi fishes which is called with many common names such as benayne, hmarriya sefra, dunbuk kabir al-fam, in most city of Iraq, but in Mosul they call it dumbek (= meaning solid or compact flesh), it considered a good source of food, it distributed in Syria freshwater as well as Iraqi, it having a longer coiled intestine and more gill rakers. Length may be reaches $19.3 \mathrm{~cm}$. It distributed in Tigris and Euphrates rivers in Syria, In Iraq it is founds in large rivers, the Tigris, Euphrates and Al-masab Al-Amm (Main Outfall Drain), as well as lakes such as Tharthar, Habbaniyah and Razzazah, in Al Qadisiyah, Derbendikhan, and Dukan reservoirs as well as in marshes. This fish found and can be collected from varies habitats as it mentioned above as well as canals and gravel pits. Benayne fish could survive in about $37^{\circ} \mathrm{C}$. Major food items are of plant origin but it showed an omnivorous diet, copepods and cladocerans are found in its Guts with some green algae. And thought to be an accidental food item is Zooplankton (Beckman,(1962); Coad, (2010))

Review for some studies about its parasites infections, this fish C. macrostomum, had been infected with many end-ectoparasites, Glaridacris oligorchis had been found by Rahemo and Mohammad, (2004).

The spices Dogielius molnari had been recoded for the first time in Iraq from Greater Zab river by Abdullah and Mhaisen (2005). Then Abdullah and Mhaisen (2006) found two protozoan Ichthyophthirius multifilliu and Trichodina domerguei and one crustacean Pseudolamproglena annulata the three parasite were collect from skin and gill of this fish from Greater Zab river.

Two protozoan I. maltifiliis and Myxobolus pfeifferi, one monogenea Octomacrum earopaeum and one Molluscan Unio pictorum had been found by Al-s'sadi, (2007).

Bilal, and Abdullah, (2008) was found three crustacean Ergasilus barbi, Lamproglena pulchelia and $P$. annulata, this fish was consider as a new host for the spices $L$, pulchelia in them study.

The species Dactylogyrus cyprinioni was recorded for the first time in Iraq on this fish by Abdullah, (2009) from Darbandikan lake. Parasites from the Diplozoidae family was isolated by Al-Nasiri, (2009) from this fish, $D$. barbi, $D$. paradoxum, Pradiplozoon bliccae and $P$. pavlovskii, the spices $P$. bliccae was recorded for the first time in Iraq on this fish, and regarded as a new host for $D$. paradoxum in her study.

Abdullah, and Mhaisen, (2010) founds two Digenetic trematoda Clinostomum complanatum and Diplostomum spathaceum in this fish, from Greater Zab and Lesser Zab rivers, north of Iraq.

Al-Nasiri, (2010) record the Monogenea Diplozoidae, $P$. amurensis for the first time in Iraq from this fish C. macrostomum. Then Al-Nasiri, (2013) record the protozoan parasites Myxidium rhodei on this fish 
and it considered as a new host, and recorded Myxobolus museuli for the first time in Iraq and the fish as a new host.

Abdullah, and Abdullah, (2013) isolate two monogeneans one as a new record in Iraq, D. reinii and the other was $D$. molnari the fish also considered as a new host for the firs parasite from Darbandikan lake.

Al-Jawda and Asmar (2014) isolate four monogenea D. anchoratus, D. skrjabini, D. varicorhini and Gyrodactylus baicalensis, they refered to $C$. macrostomum fish as a new host for the first and the second parasites of it, and two digenea Ascocotyle coleostoma and Diplostomum spathaceum.

The C. macrostomum fish as a new host for three monogenea, Dogilius mokhayeri, D. persicus and Paradiplozoon homoion by Abdullah, and Nasraddin (2015) from Lesser Zab river.

\section{Materials and Methods:}

Samples were collecting during July 2018, from Euphrates river Al-mussab city from fishermen, nine fishes of benayne, C. macrostomum. it had been measured and weighted, its weight 8.5-46 gm, and its length $9.5-16 \mathrm{~cm}$ respectively and then examined. Fishes were killed by anesthesia by cutting spinal cord and examined for parasites funa by taking smear from their skin, fins and Gills by scalpel gently push toward the slide. Gills were cut and put it in Petri dishes full of normal saline then make smear from it and examined under combined microscope. Smears were attenuate by saline drop with a needle, then examine without cover slide and after parasite arise the feces dirt well be removed from slid then dried the smear well and but the Canada belsam, finally cover it with cover slide. All parasites were prepared in the same way. Parasites were Measurement, then identification by comparing it with the taxonomy references and studies before. The records of new hosts for these parasite were checked with the Index-catalogue by Mhaisen, F.T. (2019).

\section{Results And Discussion:}

Fish specimens were collected, and examined and through out examining the slides of the nine fishes noticed a ciliated parasite in two fishes smear, after looking and searching the taxonomy references and theses, The investigation about this ciliate deals with what Al-Musawi, (2016) recoded and the measurement equalized to what he mention and what Warren, (1989) described, then by e-mailing Pro. Dr. F.D. Mhaisen, and after he check his Index-catalogue, Mhaisen, F.T. (2019) the parasite considered as a new intrusive on C. macrostomum. and this fish considered as a new host for it in Iraq.

Acknowledgements:

I am grateful to Pro. De. Furhan T. Mhaisen for access to his catalogue Index-catalogue of parasites and disease agents of fishes of Iraq and gave me the knowledge that the parasite Vorticella globularia considered as a new intrusive on Cyprinion macrostomum and this fish as a new host for it in Iraq.

\section{References}

1. Abdullah, S.M.A. (2009). Additional Records of Dactylogyrus (Monogenea) from Some Cyprinid Fishes from Darbandikhan Lake, Iraq. Jordan J. of Biol. Sci. (ISSN 1995-6673)Vol. 2, (4): 145 - 150.

2. Abdullah, Y.S. and Abdullah, S.M.A. (2013). Monogenean Infections on Fishes from Darbandikan Lake in Kurdistan Region, Iraq. Basrah J. Agric. Sci., 26 (Spec. Issue 1):117-131.

3. Abdullah, S.M.A. and Nasraddin, M. O. (2015). Monogenean Infections on Some Fishes from Lesser Zab River, Kurdistan Region, Iraq. Amer. J. of Biol. and Life Sci. 3(5): 161-167.

4. Abdullah, S.M.A. \& Mhaisen, F.T. (2005). The first record of three species of Dogielius (Monogenea) from three cyprinid fishes from the Greater Zab River, north of Iraq. Ibn Al-Haitham J. Pure Appl. Sci., 18(3): 7-12.

5. Abdullah, S. M. A. and Mhaisen, F. T. (2006). Parasitic infections with protozoa and crustacea on fishes of Lesser Zab and Greater Zab Rivers, north of Iraq. Proc. $4^{\text {th }}$ Sci. Conf. Coll. Vet. Med., Univ., Mosul / 20-21 Sept. 2006, 1: 51-58. 
6. Abdullah, S.M.A. and Mhaisen, F.T. (2010). Comparative study on the parasitic infections of some sympatric fish species in Greater Zab and Lesser Zab rivers, north of Iraq. Basrah J. Agric. Sci., 23 (Spec. Issue 2): 70-80.

7. Al-Jawda and Asmar (2014). Monogeneans and Trimatodes of some fishes from Tigris river at north, mid and south of Baghdad province, Iraq. Iraqi J. Agric. Res. (Special Issue) Vol.19 (1): 193-202.

8. Al-Musawi, A.M.K. (2016). Epidemiological study of external parasites that parasitic on Planiliza abu in three different habitats in the province of Babylon. [M. Tech. thesis], Al-Musaib technical college, Tech. Univ. Al-Furat Al-Awsat. 135pp., (in Arabic).

9. Al-Nasiri, F.S. (2009). Diplozoid species (Monogenea) parasitizing gill of some Cyprinid fishes from Tigris river passing though Tikreet city, Salah Al-Deen province, Iraqi J. Agric. (Special Issue) Vol. 14 (5): 184188.

10. Al-Nasiri, F.S. (2010). First record of Paradiplozoon amurensis (Monogenea: Diplozoidae) in Iraq from gills of the cyprinid fish Cyprinion macrostomum. Parassitologia 52: 439-440.

11. Al-Nasiri, F.S. (2013). Protozoan parasites of five fish species from the Tigris river in Salah Al- Deen province, Iraq. J. Tikrit Agri. Sci.,13(1): 355-359.

12. Al-Sa'adi, B. A.-H. E. (2007). The parasitic fauna of fishes of Euphrates River: applied study in Al-Musaib city [M. Tech. thesis], Foundation of Technical Education, Baghdad, Iraq. 102pp., (in Arabic).

13. Beckman, W.C. (1962). The fresh water fishes of Syria and their general biology and management. FAO Fish. Biol. Tech. Pap. 8, v +297 pp.

14. Bilal, S. J. and Abdullah, S.M. A. (2008). Protozoa and Crustacea infesting some Cyprinid fishes from Bahdinan river in Kurdistan region-Iraq. J. Duhok Univ. Vol.12 (1) (Special Issue):108-112.

15. Coad, B.W. (2010). Freshwater fishes of Iraq. Pensoft Publ. Sofia, Moscow: 294 pp.

16. Mhaisen, F. T. (2019). Index-catalogue of parasites and disease agents of fishes of Iraq (Unpuplished: mhsisenft@yahoo.co.uk.).

17. Rahemo, Z. I. F. and Mohammad, S. A. (2004). Four species of monozoic cestodes from the intestine of cyprinid fishes in Iraq. Dirasat (Med. Biol. Sci.), 31(2): 149-155, (In Arabic).

18. Warren, A. (1986). A revision of the genus Vorticella (Ciliophora: Peritrichia). Bull. British Mus. Nat. Hist., 50:1-57. 